\title{
Examining the Relationship between Land Values and Credit Availability
}

\author{
Ana Claudia Sant'Anna ${ }^{1, *(1)}$, Cortney Cowley ${ }^{2}(1)$ and Ani L. Katchova ${ }^{3}(1)$ \\ ${ }^{1}$ Division of Resource Economics and Management, West Virginia University, Morgantown, U.S.A, ${ }^{2}$ Regional Affairs \\ Department, Federal Reserve Bank of Kansas City, Oklahoma City, U.S.A and ${ }^{3}$ Agricultural, Environmental, and \\ Development Economics Department, The Ohio State University, Columbus, U.S.A \\ ${ }^{\star}$ Corresponding author. Email: anaclaudia.santanna@mail.wvu.edu
}

\begin{abstract}
Increased credit availability facilitates land acquisition, but higher land values also hinder it. We investigate the impact of credit availability on land values, after regulatory changes in the lending system. We build an index of increased credit availability using Federal Reserve and Federal Deposit Insurance Corporation data. County-level panel fixed effects estimations are performed controlling for land value determinants, credit availability, and county-level macroeconomic factors. We find that estimating the effects of credit availability separately masks its total effect. Results show a 0.1 change in the index for increased credit availability is associated with $1.64-1.96 \%$ increase in land values.
\end{abstract}

Keywords: Ag Credit Survey; farm loans; fixed effects; interest rates; land values

JEL Classifications: G21; Q14; Q15

\section{Introduction}

Credit constraints can limit land investments and farm productivity (Pederson, Chung, and Nel, 2012). Increased credit availability, though, can have both favorable and unfavorable consequences. While increasing credit access may facilitate land acquisition, more credit can put upward pressure on land values making it harder for farmers to acquire land. Increases in land values contribute to greater wealth of farmers who own land, allowing them to accumulate more debt as they may take on further loans to buy land. This may also generate inequality with respect to land acquisition, increasing barriers to enter into farming. For lenders who seek to maximize loan volume while reducing default losses, increasing land values may foster a demand for loans that supersedes supply, impacting credit availability. Additionally, knowledge of the impact of credit availability on land values may help lenders when managing loan portfolio risk (Zakrzewicz, Brorsen and Briggeman, 2013). To avoid the repercussions of increasing land values, as experienced in the 1980s, changes have been made to the lending system. In light of these changes, we investigate the current impact of credit availability on land values.

Since the 1980's farm crisis, the lending system has gone through a number of changes especially in relation to the role of collateral and how collateral is estimated (Zhang and Tidgren, 2018). First, agricultural lenders are required to also rely on cash flow statements ${ }^{1}$ in addition

\footnotetext{
${ }^{1}$ Cash flows statements provide information on cash flows in and out of the operation for operating, financing, and investment activities over a period of time (Barry and Ellinger, 2012). Cash flow statements provide the lender information on the financial health of the operation in greater detail and more frequently (e.g. monthly or quarterly).

(C) The Author(s) 2021. Published by Cambridge University Press on behalf of the Southern Agricultural Economics Association. This is an Open Access article, distributed under the terms of the Creative Commons Attribution-NonCommercial-NoDerivatives licence (http:// creativecommons.org/licenses/by-nc-nd/4.0/), which permits non-commercial re-use, distribution, and reproduction in any medium, provided the original work is unaltered and is properly cited. The written permission of Cambridge University Press must be obtained for commercial reuse or in order to create a derivative work.
} 
to relying on collateral. "Expected multi-year-average operating cash flow" (Zhang and Tidgren, 2018, p. 401) instead of current market prices should be used to estimate collateral values. As such, returns from operations are considered instead of the current market land value, which is more vulnerable to changes in inflation and investor speculation. Second, loan-to-value ratios below $85 \%$ are required. Third, agricultural lenders put greater emphasis on repayment capacity (i.e. the capacity of an operation to generate enough cash from sales in relation to its debt (Barry et al., 2012) $)^{2}$. We investigate how these developments have changed how credit availability, measured using several bank-reported and derived indicators, affects land values.

Although previous research has explored the relationship between land values and debt, these studies have limited their measurement of credit to the total amount of liabilities extended to or held by farmers. Using this measure of credit may underestimate the effects of credit on land values as it relies on the amount of debt held by farmers, which may not be as easily observed. Briggeman, Koenig and Moss (2012) discuss how information on debt held by farmers is limited since a large portion of credit suppliers do not provide information on their lending activities. We provide a new look at the effects of credit availability on land values by arguing that credit availability is a broader concept than total debt. Therefore, we measure credit through changes in bank markets at the county level as in Rajan and Ramcharan's (2015) study and by considering agricultural lenders' responses to changes in collateral requirements (amount of collateral that is necessary to secure a real estate loan), available funds (bank deposits), and repayment rates (the frequency with which loans are being repaid on time and/or in full). We combine these factors into an index for increased credit availability and examine its effects on land values.

This study provides insights for government programs that support the acquisition of land through increases in credit availability. Lack of access to land hinders farmers from starting or expanding their farm operations. There are government programs in place to help farmers (especially beginning farmers and ranchers) to acquire land (e.g. Farm Service Agency Direct Farm Ownership Microloans program) (Bigelow, Borchers and Hubbs, 2016). Results point to increases in land values if more lenders perceive favorable credit conditions, which may increase the challenges facing those seeking to acquire land. Accurate knowledge of trends in land values due to increased credit availability helps lenders manage portfolio risks. Our study contributes to the literature on the relationship between credit and land values by introducing a new way of measuring credit availability and by showing that, even after the regulatory changes incurred to the lending system, credit availability still has a considerable effect on land values.

\section{Measuring Credit: A Look at Past Studies}

Agricultural credit conditions can affect economic growth (Hartarska, Nadolnyak, and Shen, 2015), as well as farm productivity (Ciaian, Fałkowski, and Kancs, 2012) and investments (Pederson, Chung and Nel, 2012). Studies analyzing the effects of credit on investments and farm productivity generally represent credit by total debt or total loan amount (Table 1). Nevertheless, there are a number of studies that rely on surveys or the development of credit classifications from secondary data to describe credit. Another way to proxy credit is described in Rajan and Ramcharan's (2015) study, where elements that affect credit supply are considered (e.g. number of banks and bank deposits).

Devadoss and Manchu (2007) find that a $1 \%$ increase in credit availability, in the form of loans granted through the Farm Service Agency, increases land values by $1.4 \%$. They model credit as one of the determinants of land values and estimate a fixed effects panel regression using county-level data from Idaho. Agricultural loans are also used in Hartarska, Nadolnyak, and Shen (2015) to examine the effects of agricultural credit on the economic growth of U.S. states and regions. They

\footnotetext{
${ }^{2} \mathrm{An}$ evaluation of repayment capacity may also consider other sources of wealth, such as off-farm income and private properties.
} 
Table 1. Definitions or proxies for credit availability found in previous studies

\begin{tabular}{|c|c|c|}
\hline Source & Credit variable & Further comments \\
\hline Hartarska, Nadolnyak and Shen (2015) & $\begin{array}{l}\text { Loans granted by commercial } \\
\text { banks and FCS }\end{array}$ & \\
\hline \multirow[t]{2}{*}{ Rajan and Ramcharan (2015) } & Number of banks & $\begin{array}{l}\text { More competition for depositor } \\
\text { funds and greater credit supply }\end{array}$ \\
\hline & Amount deposited in banks & $\begin{array}{l}\text { Proxy for liquidity and lending } \\
\text { capacity }\end{array}$ \\
\hline Cole (1998) & Denied or extended credit & \\
\hline Shalit and Schmitz (1984) & Amount of debt & \\
\hline Fletschner (2008) & $\begin{array}{l}\text { Questions eliciting access to } \\
\text { credit status }\end{array}$ & $\begin{array}{l}\text { Questions such as if respondents } \\
\text { took on a loan, whether they } \\
\text { were denied a loan, whether } \\
\text { they received the full amount } \\
\text { they had applied for }\end{array}$ \\
\hline Penderson, Chung and Nel (2012) & Farm liabilities & \\
\hline Briggeman, Towe and Morehart (2009) & $\begin{array}{l}\text { Examines credit access by catego- } \\
\text { ries ranging from applied for a } \\
\text { loan and received it, to denied a } \\
\text { loan. }\end{array}$ & \\
\hline Hartarska and Nadolnyak (2012) & $\begin{array}{l}\text { Share of respondents with(out) } \\
\text { loans. Share of respondents } \\
\text { where having a collateral was an } \\
\text { obstacle to receive the loan. }\end{array}$ & \\
\hline Devadoss and Manchu (2007) & $\begin{array}{l}\text { Amount of loans through the } \\
\text { Farm Service Agency }\end{array}$ & \\
\hline Ciaian, Falkowski, Kancs (2012) & Total farm loans & \\
\hline
\end{tabular}

represent agricultural lending by using lagged information on loans conceded by commercial banks and by the Farm Credit System. Following Hartarska, Nadolnyak and Shen (2015), we also use lagged credit variables and interest rates.

A more in-depth analysis of the relationship between debt accumulation and land values can be found in Shalit and Schmitz $(1982,1984)$. Shalit and Schmitz (1982) built a model to illustrate the effects of debt accumulation on land values. They aggregate the individual farmer's demand for land, derived from the utility maximization problem, to arrive at the total demand for land. By applying national data to their conceptual model, Shalit and Schmitz (1984) conclude that loan extensions based on collaterals can inflate land prices in the short run. As a measurement for credit availability, the authors also use information on agricultural lenders' expectations on future land values. Currently, land value, when used as collateral, is estimated by taking into account various years and not current market prices. As such, we believe that other variables such as repayment rates, available funds, and changes to required collateral may be more appropriate measures of credit availability.

Rajan and Ramcharan (2015) use a novel form of measuring credit. With a data set ranging from the 1900s to 1930s, the authors run a number of regression models and perform graphic analysis using deposits and bank branches as proxies for credit availability. They argue that these variables explain credit supply through: (1) increased competition and greater proximity to borrowers and (2) liquidity and lending capacity. Rajan and Ramcharan (2015) argue that since lending was local in the 1920 s, the use of these variables as a proxy for credit availability is viable. When considering the longrun effects from credit availability, Rajan and Ramcharan (2015) conclude that larger declines in land values occurred in counties which, in the 1920s, had more credit availability. 
Greater credit access and availability can influence capital investment decisions. Ciaian, Falkowski, and Kancs (2012) find a positive relationship between credit, input use, capital investments, and total factor productivity. They employed a matching method, and farm credit is represented by total farm liabilities. One limitation of Ciaian, Falkowski, and Kancs (2012) is that their data include loans used but not credit access. They split the sample into eight credit classifications ranging from no loans (i.e. no credit) to a debt-to-output ratio of over $100 \%$. Likewise, Briggeman, Towe, and Morehart (2009) examine credit use and availability by building credit classes from the Survey of Consumer Finances and the Agricultural Resource Management Survey. Categories range from one, where credit is extended without obstacles to five where credit is denied.

Measurements for credit restrictions and their effects are explored in Pederson, Chung, and Nel (2012) study, and Cole (1998). Pederson, Chung, and Nel (2012) investigate how credit availability can benefit farmers. By using matching methods, they compare farmers with and without access to credit and find that with a $1 \%$ increase in loans, credit-constrained farmers can experience an increase of $0.5 \%$ in their income and $0.3 \%$ increase in investments. Cole (1998) examines the effects of the borrower-lender relationship on the lending decision by using a binary dependent variable for whether credit was denied or not and exogenous variables (e.g. checking or savings account, loans or financial services with the bank) to represent the relationship that the borrower may have with the lender. Cole (1998) finds that pre-existing borrowerlender relationships increase the potential for a lender to extend credit to a borrower.

Fletschner (2008) and Hartarska and Nadolnyak (2012) design surveys to investigate credit access. Fletschner (2008) examines the importance of the gender of the person who received credit in the household efficiencies (i.e. technical, allocative, and economic). To account for credit access, respondents were asked whether they took on a loan, if the amount requested was extended in full, or whether they were denied a loan. When examining the effects of the 2008 financial crisis on farmer's credit access, Hartarska and Nadolnyak (2012) find that although financial constraints were not associated with the financial crisis, loans were extended through collateral. To account for credit, they consider the shares of the respondents who received or applied for a loan, as well as those who did not have access to certain loans. They also have a measurement for whether the collateral requirement was an obstacle or not.

In this study, the terms credit access and credit availability are used interchangeably. Although these terms may not be identical, here we assume that there is greater access to credit if more credit is available. Credit availability is defined by "the complex of non interest rate lending terms prevailing in the market" (Guttentag, 1960, p. 222). As such, greater credit availability comes by lenders relaxing their requirements to extend a loan (e.g. collateral requirements). We assume that lenders may reduce restrictions to extend loans if available funds are higher and repayments rates are lower. We also assume that credit supply is greater in counties with a greater number of bank companies and/or with a larger amount of bank deposits (ERS/USDA 2020). We use an array of variables to represent credit availability and access, such as responses of agricultural lenders to the Federal Reserve Ag Credit Surveys, and data on deposits and bank branches from FDIC Summary of Deposits (SOD). We also control for possible loans granted online, which to the best of our knowledge has not been accounted for previously. Furthermore, we account for factors at the county level that could influence the conditions for credit such as per capita income, education, and unemployment. Last, inspired by studies that use secondary data to build classifications of credit availability, we build an index for increased credit availability.

\section{Data}

This study uses a county-level, panel data set for the years of 2002, 2007, 2012, and 2017 (Table 2). County-level data on returns to agricultural production, government payments, number of farms with internet access, and land in farms are from the Census of Agriculture. All monetary variables 
Table 2. Summary statistics

\begin{tabular}{|c|c|c|c|c|}
\hline Variable & Decription & Mean & $\begin{array}{l}\text { Standard devi- } \\
\text { ation }\end{array}$ & Source \\
\hline Land value & Land value per acre of non-irrigated farmland & $2,285.86$ & $2,023.34$ & FED $K C$ and $M N$ \\
\hline \multicolumn{5}{|l|}{ Determinants of land value } \\
\hline Return & Value of production per acre minus cost of production per acre & 53.54 & 261.26 & Agricultural Census \\
\hline Government payments & Total government payments received per acre less any conservation payments & 7.96 & 5.96 & Agricultural Census \\
\hline Population & Total population per sq. mile & 60.28 & 259.55 & U.S. Census Bureau \\
\hline Fixed interest rate & Lagged fixed interest rate on farm real estate loans & 7.88 & 1.97 & FED $\mathrm{KC}$ and $\mathrm{MN}$ \\
\hline \multicolumn{5}{|l|}{$\begin{array}{l}\text { Determinants of credit access } \\
\text { and credit availability }\end{array}$} \\
\hline Increased credit availability & Dummy indicating whether more bankers report increasing credit availability conditions & 0.12 & 0.32 & Designed by authors \\
\hline Increased credit availability index & $\begin{array}{l}\text { Dummy indicating whether more bankers report increasing credit availability conditions } \\
\text { and FDIC variables }\end{array}$ & 0.13 & 0.34 & Designed by authors \\
\hline Lower repayment rate & Percentage of replies that the repayment rate was lower in the previous 3 months & 19.96 & 27.13 & FED $K C$ and $M N$ \\
\hline Lower availability of funds & Percentage of replies that the availability of funds was lower in the previous 3 months & 20.26 & 26.05 & FED $\mathrm{KC}$ and $\mathrm{MN}$ \\
\hline Higher collateral required & Percentage of replies that the collateral required was higher in the previous 3 months & 16.35 & 23.57 & FED $K C$ and $M N$ \\
\hline Expected demand for loans & Diffusion index ${ }^{\mathrm{a}}$ on expected demand for loans in the coming 3 months. & 114.25 & 22.13 & FED $K C$ and $M N$ \\
\hline Farm credit system loans & Real estate loans per county in USD $\$ 1,000^{\star}$ & 43.53 & 59.34 & FCA \\
\hline Company & Number of different bank companies in a county & 1.10 & 2.24 & FDIC \\
\hline Deposits & Total deposits in banks in the county per $\$ 1$ Million/sq. mile & 0.57 & 22.50 & FDIC \\
\hline $\begin{array}{l}\text { Number of operations with } \\
\text { internet }\end{array}$ & Number of farm operations with internet access or use in a county & 435.12 & 276.76 & Agricultural Census \\
\hline \multicolumn{5}{|l|}{$\begin{array}{l}\text { Macroeconomic factors at the } \\
\text { county level }\end{array}$} \\
\hline Population growth & Annual percentage change in population & -0.08 & 1.55 & U.S. Census Bureau \\
\hline House value & Total value housing permits in $\$ 10$ million & 3.22 & 12.30 & U.S. Census Bureau \\
\hline
\end{tabular}

(Continued) 
Table 2. (Continued)

\begin{tabular}{|c|c|c|c|c|}
\hline Variable & Decription & Mean & $\begin{array}{l}\text { ndard devi- } \\
\text { ation }\end{array}$ & Source \\
\hline Unemployment rate & Percentage of the population, 16 years and over, that is unemployed & 4.50 & 1.92 & BLS \\
\hline Farm income per capita & Farm income per capita in USD\$1,000 & 3.21 & 4.89 & BEA \\
\hline Incomplete high school & Percentage of population that did not complete high school & 13.19 & 6.11 & U.S.D.A \\
\hline Metro County & $\begin{array}{l}\text { Dummy constructed using rural-urban continuum codes with } 1 \text { for } \\
\text { metro county and } 0 \text { otherwise }\end{array}$ & 0.18 & 0.39 & U.S.D.A \\
\hline Debt-to-income ratio & Ratio of debt to income at the household level & 1.56 & 0.83 & BLS \\
\hline
\end{tabular}

FED: Federal Reserve Bank of Kansas City and that of Minneapolis data from the Ag. Credit Survey applied to the 9th and 10th Federal Reserve Districts. FDIC: Federal Deposit Insurance Corporation. FCS: Farm Credit System call reports. USDA: U.S. Department of Agriculture. BEA: Bureau of Economic Analysis. BLS: U.S. Bureau of Labor Statistics. All values are in 2017 US\$.

aDiffusion Index $=[$ bankers responded higher $(\%)$ - bankers responded lower $(\%)]+100$

${ }^{*}$ Real estate loans from Farm Credit System from 2006, 2011, and 2016 were estimated by dividing the loans reported at the headquarters weighed by the farmland area in each county. 


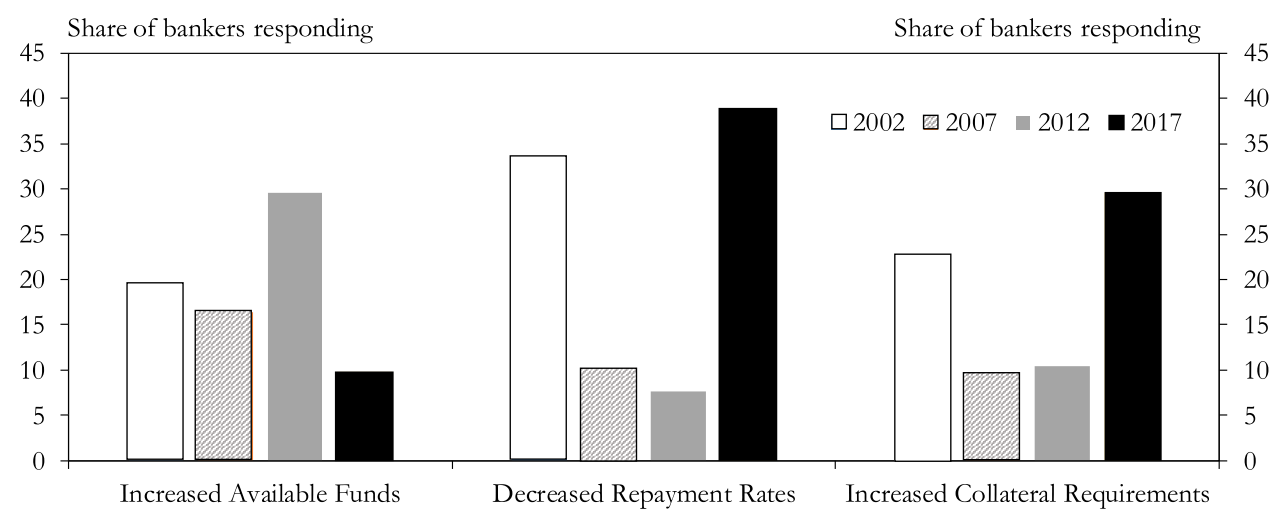

Figure 1. Determinants of credit availability from Ag Credit Survey respondents. Sources: Federal Reserve Banks of Kansas City and Minneapolis.

are divided by the total land in farms in each respective county such that values are in dollars per acre. Returns to agricultural production are estimated by subtracting total operating expenses of all agricultural commodities from total sales. Information related to population and housing come from the U.S. Census, while that on unemployment rates and household debt-to-income are from the U.S. Bureau of Labor Statistics. Data on farm income per capita come from the Bureau of Economic Analysis. Data on the percentage of the population with incomplete high school come from the United States Department for Agriculture (USDA) ${ }^{3}$. The dummy Metro, indicating whether the county is a metropolitan county or not, is built using the 2003 and 2013 UrbanRural Continuum Codes from the USDA ${ }^{4}$. Credit availability and access data come from: Federal Reserve Banks of Kansas City and Federal Reserve Bank of Minneapolis Surveys of Agricultural Credit Conditions (Ag Credit Surveys) and the Summary of Deposits from the FDIC $^{5}$.

The Kansas City and Minneapolis Federal Reserve Districts administer Ag Credit Surveys to banks in their regions. The surveys ask bank respondents questions regarding the average price for irrigated and non-irrigated cropland and ranchland, as well as, information on collateral requirements, rate of loan repayments, interest rates charged, and the availability of funds, among other questions. Respondents report numeric values for the average price of farmland and interest rates in their lending areas. For the information on collateral requirements, available funds, and rate of loan repayments, bankers respond whether, in the previous 3 months, these variables were lower, higher, or remained unchanged in comparison to a year ago. During the study period, the share of bankers reporting increased available funds had declined, while the share of those reporting decreased repayment rates increased, with respect to the previous year (Figure 1). A greater number of bankers had also reported increased collateral requirements, with respect to the year before, in the years of 2002 and 2017 (Figure 1). The Ag Credit Survey is conducted quarterly, while the Summary of Deposits (SOD) is reported annually. We match annual data from the Census and the Federal Deposit Insurance Corporation (FDIC) with data from the second quarter of the Survey of

\footnotetext{
${ }^{3}$ Given that the USDA reports this information for only a select number of years, we use data from the year 2000 as a proxy for 2002 and data from 2012-2016 as a proxy for 2012 and 2017. The average of the 2000 and 2012-2016 data is used as a proxy for 2007.

${ }^{4}$ Metro counties are considered to be those in categories 1, 2, and 3. Data for 2003 are used as a proxy for 2002 and for 2007, while data for 2013 are used as a proxy for 2012 and 2017. For further information on the categories of the Urban-Rural Continuum Codes from the USDA please read through the documentation files at https://www.ers.usda.gov/dataproducts/rural-urban-continuum-codes/documentation/

${ }^{5} \mathrm{We}$ do not use information on agricultural loans since these are informed at the bank headquarter level. Information and bank location and deposits are available at the branch level.
} 
Agricultural Credit Conditions. Given that the Census information is collected in the middle of the year, it is reasonable to match it to that of the second quarter for the Survey of Agricultural Credit Conditions.

Although around $30-40 \%$ of real estate loans are conducted through the Farm Credit System (FCS) (ERS/USDA 2020), we are unable to consider the impact of those loans in our model. The FCS call reports only provide information on agricultural loans at the association headquarter level. Information on the agricultural loans awarded to each county are not recorded, and FCS institutions can serve more than one state (Nadolnyak, Shen and Hartarska, 2017). Additionally, information on agricultural loans for real estate ${ }^{6}$ are only available from 2005 onwards (Nadolnyak et al., 2017). Given these limitations, FCS loans are used only to test the sensitivity of credit availability when also accounting for FCS loans. By assuming that Farm Credit associations only grant loans within the state they are in, we weigh the total agricultural real estate loans by the total amount of farmland in each county.

To assess the total effect of credit availability on land values, an index for increased credit availability was created. It represents bankers' views on factors that could support higher credit availability. It is equal to one if the respondent answered that, in comparison to the previous year, repayment rates were higher, collateral was lower, and available funds were higher than in previous 3 months. Otherwise the index is zero.

The area for this study comprises the Minneapolis (Ninth) and Kansas City (Tenth) Federal Reserve Districts. The Ninth District encompasses the states of Minnesota, Montana, North Dakota, South Dakota, the Upper Peninsula of Michigan, and northwestern Wisconsin. The Tenth District encompasses the states of Wyoming, Oklahoma, Colorado, Kansas, Nebraska, the northern half of New Mexico, and the western third of Missouri. The study is restricted to this area since the data on credit availability come from the Ag Credit Survey applied to the Ninth and Tenth Federal Reserve Districts. The area contains a greater concentration ( 60\%) of agricultural banks (i.e. those with at least $15 \%$ of their loans in agriculture) (Koenig, 2016). According to Federal Financial Institutions Examinations Council (FFIEC) call reports, close to $45 \%$ of total agricultural loans in the U.S. come from banks in these two districts.

\section{Conceptual Framework and Empirical Strategy}

Land value models generally are rooted on the basic definition of farmland price as the sum of its discounted future returns (Moss and Katchova, 2005). The idea being that farmland value would be equivalent to its future returns:

$$
\text { Land } \text { Value }_{0}=E\left[\sum_{t=1}^{\infty} \frac{\text { Returns }_{t}}{\left(1+{\text { discount rate })^{t}}^{t}\right.}\right] .
$$

Research, however, has shown that land values are affected by other factors than only discounted future returns. Newer variations to equation (1) include the addition of factors such as government payments and housing values (Goodwin, Mishra and Ortalo-Magné, 2003; Goodwin, Mishra and Ortalo-Magné, 2011), urbanization pressures (Kuethe, Ifft and Morehart, 2011), as well as financial factors such as inflation and loans (Devadoss and Manchu, 2007; Just and Miranowski, 1993). In this paper, we expand the financial factors considered previously to include credit availability. We argue that credit availability extends beyond the total amount of loans used in the past. Therefore, we proxy credit availability by lending terms and market expectations of bankers. We assume that increased credit availability will increase demand for land adding pressure to land values.

Our empirical strategy is based on equation (1) plus the variables used to determine land values found in previous studies (e.g. Borchers, Ifft and Kuethe, 2014; Devadoss and Manchu, 2007;

\footnotetext{
${ }^{6}$ Prior to 2005, FCS call reports inform the total amount in agricultural loans (i.e. production loans plus real estate loans).
} 
Goodwin, Mishra and Ortalo-Magné, 2003) along with other variables that represent credit availability. We estimate the impact of credit availability on land values by running a log-linear estimation of the natural logarithm of land values against land value determinants $\boldsymbol{X}_{i t}$, credit availability factors $Z_{i t}$, and county and macroeconomic factors $W_{i t}$ :

$$
\ln \text { land } \text { value }_{i t}=\alpha_{i}+\beta \boldsymbol{X}_{i t}+\delta \boldsymbol{Z}_{i t}+\theta \boldsymbol{W}_{i t}+\delta_{i}+\tau_{t}+\varepsilon_{i t} \text {. }
$$

We also control for county-level fixed effects $\left(\delta_{i}\right)$ and year fixed effects $\left(\tau_{t}\right)$. $\varepsilon_{i t}$ denotes the error term which has a mean of zero. Although we have split the control variables into three categories (land values determinants, credit availability factors, and county and macroeconomic factors), some variables could belong to more than one category.

Land value determinants $X_{i t}$ are returns, interest rates, government payments, and urbanization pressures. Following the capitalization model, land values are the sum of the expected future returns for the land discounted using a discount factor (e.g. interest rate). Hence, returns and interest rates are considered the fundamental variables (Featherstone and Baker, 1987). Apart from the fundamental variables, we also account for other factors which may determine land values. These are government payments and population density. Following Goodwin, Mishra and Ortalo-Magné (2003), we represent urbanization pressures using population per square mile and account for the impact from government payments ${ }^{7}$.

Credit availability factors $Z_{i t}$ encompass variables from the Ag Credit Survey conducted by the Ninth and Tenth Federal Reserve Districts and from the FDIC SOD. Control variables from the Ag Credit Survey are responses from agricultural lenders on whether loan repayment rates are lower, collateral requirements are higher, and whether available funds have increased in comparison to the past 3 months. These variables provide insights into the lending practices ${ }^{8}$ and expectations of agricultural lenders. Following Rajan and Ramcharan (2015), we also control for the number of different banks and for bank deposits. Although online banking is becoming more common, having a bank in a county allows for the establishment of a stronger lender-borrower relationship which affects the amount of loans granted (Rajan and Ramcharan, 2015; Keeton, 1996; Cole, 1998). Nevertheless, we consider online banking by controlling for the number of farm operations with internet. We assume that farms with internet access and use have a higher probability of obtaining a loan online than those without internet access. Additionally, internet access and use by a farm business have been linked to gains in efficiency and productivity (Hennessy, Läpple and Moron, 2016). Increased access to information can impact not only a farmer's banking decision but also their production and land conservation decisions which, in turn, affects land values.

We also control for county and macroeconomic factors, which may affect land values, and the variables related to credit availability (e.g. creditworthiness of a county). County and macroeconomic factors $\left(W_{i t}\right)$ are population growth, housing permit values, unemployment rates, farm income per capita, percentage of the population with incomplete high school, debt-to-income ratio, and whether the county is urban or rural. Population growth, unemployment rates, education, and income control for the economic development of a county. For example, Drescher and McNamara (1999) use unemployment as a measure of future economic growth. A county that is growing in population may pressure land values upwards because of higher non-agricultural capital gains to farmland. Economic growth can have an effect on the banking market, affecting the

\footnotetext{
${ }^{7}$ In this study we do not control for each government payment program separately as is done in Goodwin, Mishra and Ortalo-Magne (2003).

${ }^{8}$ For example, when studying farmers in Alabama Hartarska and Nadolnyak (2012) find that lending was primarily collateral driven.
} 
number of banks and deposit levels. The potential for economic growth of a county can also affect lenders' perceptions on repayment rates and available funds.

\subsection{Endogeneity and Identification Issues}

When dealing with land values and agricultural real estate loans, certain issues can hinder the correct identification of the credit availability coefficient. For instance, increases in collateral could affect land values, but reverse causality could also be present. Increases in land values could motivate lenders to increase collateral requirements to reflect the changes in land markets. To avoid reverse or even simultaneous causality, information on land values and on credit availability are used from different time periods. Information on land values are from responses given in the 4th quarter, while information on credit availability variables from the Ag Credit survey are from the 2nd quarter of the same year. Additionally, credit availability variables from the Ag Credit survey reflect agricultural lenders' opinion about the variations in credit availability from 3 months prior. Therefore, the information on credit availability reflects conditions at the beginning of the year, while information on land values reflects market conditions at the end of the year. Responses on land values and credit conditions are provided by the same individual; therefore, by considering two different time periods, we can potentially control for the event that the lenders' responses to changes in credit availability are influenced by their response to current land values (i.e. reverse causality).

Following Hartarska, Nadolnyak and Shen (2015), we use lagged interest rate to account for possible contemporaneous endogeneity, when times of high credit availability could occur at times of high land values. Bellemare, Masaki and Pepinsky (2017) suggest using lags to avoid endogeneity when theory suggests that causal effects occur in lags. Basha, Zhang and Hart (2020) find that lagged interest rates have a greater impact on land values than current interest rates even though current farm income has a more immediate impact which declines over time. Thus, we use lagged interest rates in our estimation.

We control for county-level factors to account for other variables that could explain the greater credit availability in a county. By running fixed effects models, we account for characteristics associated with counties and land in these counties that are fixed through time or have very small changes (e.g. soil type). We also control for year fixed effects, to account for factors that occur in a given year and affect all counties. For example, year dummies control for the increased crop receipts which occurred in 2012-2013 and may have affected land values. By controlling for county and year fixed effects, we expect to remove the majority of unobserved heterogeneity present in counties or in a given year (Bellemare and Nguyen, 2018).

The decision to use fixed effects rather than random effects was based on the Hausman test. With a critical value of $\chi^{2}=328.15$, the null hypothesis of the use of a random effects model was rejected at a $1 \%$ significance level. Additionally, we assess the fit of our model by examining the $R^{2}$, which are between 0.5 and 0.6 depending on the model (Tables 3, 4, 5 and 6). A large proportion of the variation is explained by the individual-specific terms, as indicated by $\rho$ of 0.80 or higher depending on the model (Tables 3, 4, 5 and 6). In other words, only $20 \%$ or less of the variation is due to the idiosyncratic error.

We estimate several models to identify the effects of credit availability on land values. First, we consider each factor associated with credit availability separately (i.e. the repayment rate, availability of funds, collateral requirements, number of banks and deposits in banks). Then, we form an index for increased credit availability, which takes on the value of 1 when credit is more readily available and 0 otherwise. The index for increased credit availability has the advantage of controlling for possible multicollinearity issues that may arise between the credit availability variables, by combining them into one variable. Increased credit availability is set to be equal to 1 when the following combination of factors occurs: (a) more bankers report available funds to have increased or remained unchanged in the past months; (b) more bankers declare repayment rates to have 
Table 3. Effects of individual credit measures on land values

\begin{tabular}{|c|c|c|c|c|c|c|c|}
\hline & $\begin{array}{l}\text { Log land } \\
\text { value }\end{array}$ & $\begin{array}{l}\text { Log land } \\
\text { value }\end{array}$ & $\begin{array}{l}\text { Log land } \\
\text { value }\end{array}$ & $\begin{array}{l}\text { Log land } \\
\text { value }\end{array}$ & $\begin{array}{l}\text { Log land } \\
\text { value }\end{array}$ & $\begin{array}{l}\text { Log land } \\
\text { value }\end{array}$ & $\begin{array}{l}\text { Log land } \\
\text { value }\end{array}$ \\
\hline & (1) & (2) & (3) & (4) & (5) & (6) & (7) \\
\hline \multirow[t]{2}{*}{ Return } & $0.0004^{*}$ & $0.0004^{\star}$ & $0.0004^{\star}$ & $0.0004^{*}$ & $0.0004^{\star \star}$ & $0.0004^{\star}$ & $0.0004^{\star \star}$ \\
\hline & $(0.0002)$ & $(0.0002)$ & $(0.0002)$ & $(0.0002)$ & $(0.0002)$ & $(0.0002)$ & $(0.0002)$ \\
\hline \multirow{2}{*}{$\begin{array}{l}\text { Increased availability of } \\
\text { funds }\end{array}$} & $0.0010^{\star}$ & $0.0009^{\star}$ & & & & & $0.0010^{*}$ \\
\hline & $(0.0006)$ & $(0.0006)$ & & & & & $(0.0006)$ \\
\hline \multirow[t]{2}{*}{ Higher required collateral } & -0.0007 & & -0.0006 & & & & -0.0007 \\
\hline & $(0.0006)$ & & $(0.0006)$ & & & & $(0.0006)$ \\
\hline \multirow[t]{2}{*}{ Lower repayment rate } & 0.0004 & & & 0.0003 & & & 0.0004 \\
\hline & $(0.0006)$ & & & $(0.0006)$ & & & $(0.0006)$ \\
\hline \multirow[t]{2}{*}{ Government payments } & $-0.0093^{\star \star}$ & $-0.0095^{\star \star}$ & $-0.0104^{\star \star}$ & $-0.0108^{\star \star}$ & $-0.0104^{\star \star}$ & $-0.0106^{\star \star}$ & $-0.0089^{\star \star}$ \\
\hline & $(0.0044)$ & $(0.0043)$ & $(0.0042)$ & $(0.0043)$ & $(0.0042)$ & $(0.0042)$ & $(0.0043)$ \\
\hline \multirow[t]{2}{*}{ Population } & 0.0009 & 0.0008 & 0.0007 & 0.0007 & 0.0007 & 0.0006 & 0.0009 \\
\hline & $(0.0010)$ & $(0.0010)$ & $(0.0010)$ & $(0.0010)$ & $(0.0010)$ & $(0.0010)$ & $(0.0010)$ \\
\hline \multirow[t]{2}{*}{ Fixed interest rate } & -0.0079 & -0.0086 & -0.0090 & -0.0096 & -0.0093 & -0.0098 & -0.0076 \\
\hline & $(0.0140)$ & $(0.0140)$ & $(0.0139)$ & $(0.0139)$ & $(0.0139)$ & $(0.0139)$ & $(0.0140)$ \\
\hline \multirow{2}{*}{$\begin{array}{l}\text { Number of operations } \\
\text { with internet }\end{array}$} & -0.0001 & -0.0001 & -0.0001 & -0.0001 & -0.0001 & -0.0001 & -0.0001 \\
\hline & $(0.0003)$ & $(0.0002)$ & $(0.0003)$ & $(0.0003)$ & $(0.0003)$ & $(0.0002)$ & $(0.0003)$ \\
\hline \multirow[t]{2}{*}{ Population growth } & $0.0319^{* * *}$ & $0.0303^{\star * *}$ & $0.0321^{\star \star \star}$ & $0.0318^{\star \star \star}$ & $0.0310^{\star \star \star}$ & $0.0311^{\star \star \star}$ & $0.0315^{\star \star *}$ \\
\hline & $(0.0075)$ & $(0.0073)$ & $(0.0075)$ & $(0.0076)$ & $(0.0074)$ & $(0.0074)$ & $(0.0074)$ \\
\hline \multirow[t]{2}{*}{ House value } & 0.0070 & 0.0071 & 0.0071 & 0.0069 & 0.0072 & 0.0070 & 0.0073 \\
\hline & $(0.0049)$ & $(0.0049)$ & $(0.0049)$ & $(0.0050)$ & $(0.0047)$ & $(0.0050)$ & $(0.0046)$ \\
\hline \multirow[t]{2}{*}{ Metro County } & 0.0111 & 0.0063 & 0.0068 & 0.0085 & 0.0065 & 0.0070 & 0.0136 \\
\hline & $(0.0673)$ & $(0.0671)$ & $(0.0677)$ & $(0.0682)$ & $(0.0673)$ & $(0.0679)$ & $(0.0665)$ \\
\hline \multirow[t]{2}{*}{ Debt-to-income ratio } & 0.0312 & 0.0296 & 0.0304 & 0.0283 & 0.0294 & 0.0291 & 0.0326 \\
\hline & $(0.0253)$ & $(0.0254)$ & $(0.0252)$ & $(0.0252)$ & $(0.0254)$ & $(0.0253)$ & $(0.0254)$ \\
\hline \multirow[t]{2}{*}{ Unemployment rate } & -0.0188 & -0.0189 & -0.0188 & -0.0187 & -0.0195 & -0.0189 & -0.0197 \\
\hline & $(0.0148)$ & $(0.0149)$ & $(0.0147)$ & $(0.0148)$ & $(0.0147)$ & $(0.0148)$ & $(0.0147)$ \\
\hline \multirow[t]{2}{*}{ Farm income per capita } & $0.0124^{\star \star \star}$ & $0.0123^{\star \star \star}$ & $0.0126^{\star \star \star}$ & $0.0129^{\star \star \star}$ & $0.0126^{\star \star \star}$ & $0.0128^{\star \star \star}$ & $0.0124^{\star * *}$ \\
\hline & $(0.0041)$ & $(0.0040)$ & $(0.0040)$ & $(0.0041)$ & $(0.0040)$ & $(0.0040)$ & $(0.0041)$ \\
\hline \multirow[t]{2}{*}{ Incomplete high school } & -0.0017 & -0.0019 & -0.0020 & -0.0017 & -0.0020 & -0.0020 & -0.0019 \\
\hline & $(0.0074)$ & $(0.0072)$ & $(0.0073)$ & $(0.0074)$ & $(0.0072)$ & $(0.0073)$ & $(0.0073)$ \\
\hline \multirow[t]{2}{*}{ Company } & & & & & -0.0057 & & -0.0062 \\
\hline & & & & & $(0.0065)$ & & $(0.0064)$ \\
\hline \multirow[t]{2}{*}{ Deposits } & & & & & & $0.0004^{\star \star \star}$ & $0.0004^{\star \star \star}$ \\
\hline & & & & & & $(0.0000)$ & $(0.0001)$ \\
\hline \multirow[t]{2}{*}{ Constant } & $6.3856^{\star \star \star}$ & $6.4034^{\star \star \star}$ & $6.4344^{\star \star \star}$ & $6.4348^{\star \star \star}$ & $6.4360^{\star \star \star}$ & $6.4464^{\star \star \star}$ & $6.3847^{\star \star \star}$ \\
\hline & $(0.2711)$ & $(0.2656)$ & $(0.2608)$ & $(0.2662)$ & $(0.2613)$ & $(0.2609)$ & $(0.2717)$ \\
\hline
\end{tabular}


Table 3. (Continued)

\begin{tabular}{|c|c|c|c|c|c|c|c|}
\hline & $\begin{array}{l}\text { Log land } \\
\text { value }\end{array}$ & $\begin{array}{l}\text { Log land } \\
\text { value }\end{array}$ & $\begin{array}{l}\text { Log land } \\
\text { value }\end{array}$ & $\begin{array}{l}\text { Log land } \\
\text { value }\end{array}$ & $\begin{array}{l}\text { Log land } \\
\text { value }\end{array}$ & $\begin{array}{l}\text { Log land } \\
\text { value }\end{array}$ & $\begin{array}{l}\text { Log land } \\
\text { value }\end{array}$ \\
\hline & (1) & (2) & (3) & (4) & (5) & (6) & (7) \\
\hline Observations & 1,436 & 1,436 & 1,436 & 1,436 & 1,436 & 1,436 & 1,436 \\
\hline$R^{2}$ & 0.62 & 0.62 & 0.62 & 0.62 & 0.62 & 0.62 & 0.62 \\
\hline County fixed effects & Yes & Yes & Yes & Yes & Yes & Yes & Yes \\
\hline Year fixed effects & Yes & Yes & Yes & Yes & Yes & Yes & Yes \\
\hline Counties & 550 & 550 & 550 & 550 & 550 & 550 & 550 \\
\hline$\rho$ & 0.82 & 0.82 & 0.82 & 0.82 & 0.82 & 0.82 & 0.82 \\
\hline
\end{tabular}

Notes: ${ }^{\star} 10 \%$, ${ }^{\star \star} 5 \%$, and ${ }^{\star \star \star} 1 \%$ levels of statistical significance. Standard errors clustered at the county level.

Table 4. Effects of an aggregated credit availability measure on land values

\begin{tabular}{|c|c|c|c|}
\hline & Log land value & Log land value & Log land value \\
\hline & (1) & $(2)$ & (3) \\
\hline \multirow[t]{2}{*}{ Return } & $0.0006^{\star * *}$ & $0.0006^{\star \star *}$ & $0.0005^{\star * *}$ \\
\hline & $(0.0002)$ & $(0.0002)$ & $(0.0002)$ \\
\hline \multirow[t]{2}{*}{ Increased credit availability } & $0.1790^{\star \star \star}$ & $0.1790^{\star \star \star}$ & \\
\hline & $(0.0293)$ & $(0.0293)$ & \\
\hline \multirow[t]{2}{*}{ Increased credit availability index } & & & $0.1522^{\star \star \star}$ \\
\hline & & & $(0.0287)$ \\
\hline \multirow{2}{*}{$\begin{array}{l}\text { Dummy above the average number of } \\
\text { bank companies in county }\end{array}$} & & -0.0127 & \\
\hline & & $(0.0293)$ & \\
\hline \multirow[t]{2}{*}{ Deposits } & $0.0005^{\star \star \star}$ & $0.0005^{\star \star \star}$ & \\
\hline & $(0.00004)$ & $(0.00003)$ & \\
\hline \multirow[t]{2}{*}{ Government payments } & $-0.0086^{\star *}$ & $-0.0086^{\star *}$ & $-0.0089^{\star *}$ \\
\hline & $(0.0040)$ & $(0.0040)$ & $(0.0040)$ \\
\hline \multirow[t]{2}{*}{ Population } & 0.0003 & 0.0003 & 0.0004 \\
\hline & $(0.0012)$ & $(0.0012)$ & $(0.0012)$ \\
\hline \multirow[t]{2}{*}{ Fixed interest rate } & 0.006 & 0.0061 & 0.0054 \\
\hline & $(0.0140)$ & $(0.0141)$ & $(0.0140)$ \\
\hline \multirow[t]{2}{*}{ Number of operations with internet } & 0.0001 & 0.0001 & 0.0001 \\
\hline & $(0.0002)$ & $(0.0002)$ & $(0.0002)$ \\
\hline \multirow[t]{2}{*}{ Population growth } & $0.0254^{\star \star \star}$ & $0.0253^{\star \star \star}$ & $0.0248^{\star \star \star}$ \\
\hline & $(0.0074)$ & $(0.0074)$ & $(0.0074)$ \\
\hline \multirow[t]{2}{*}{ House value } & $0.0076^{\star}$ & $0.0076^{\star}$ & $0.0082^{*}$ \\
\hline & $(0.0045)$ & $(0.0045)$ & $(0.0045)$ \\
\hline \multirow[t]{2}{*}{ Metro County } & 0.0544 & 0.0542 & 0.0417 \\
\hline & $(0.0841)$ & $(0.0839)$ & $(0.0845)$ \\
\hline \multirow[t]{2}{*}{ Debt-to-income ratio } & 0.0127 & 0.0131 & 0.0119 \\
\hline & $(0.0241)$ & $(0.0242)$ & $(0.0242)$ \\
\hline
\end{tabular}


Table 4. (Continued)

\begin{tabular}{|c|c|c|c|}
\hline & Log land value & Log land value & Log land value \\
\hline & (1) & $(2)$ & (3) \\
\hline \multirow[t]{2}{*}{ Unemployment rate } & $-0.0289^{\star \star}$ & $-0.0293^{\star \star}$ & $-0.0300^{\star *}$ \\
\hline & $(0.0119)$ & $(0.0117)$ & $(0.0120)$ \\
\hline \multirow[t]{2}{*}{ Farm income per capita } & $0.0120^{\star \star \star}$ & $0.0120^{\star \star \star}$ & $0.0123^{\star \star *}$ \\
\hline & $(0.0038)$ & $(0.0038)$ & $(0.0038)$ \\
\hline \multirow[t]{2}{*}{ Incomplete high school } & 0.0019 & 0.0019 & 0.0021 \\
\hline & $(0.0070)$ & $(0.0069)$ & $(0.0070)$ \\
\hline \multirow[t]{2}{*}{ Constant } & $6.2033^{\star \star \star}$ & $6.2051^{\star \star \star}$ & $6.2148^{\star \star \star}$ \\
\hline & $(0.2518)$ & $(0.2499)$ & $(0.2523)$ \\
\hline Observations & 1,557 & 1,557 & 1,557 \\
\hline$R^{2}$ & 0.58 & 0.58 & 0.57 \\
\hline County fixed effects & Yes & Yes & Yes \\
\hline Year fixed effects & Yes & Yes & Yes \\
\hline Counties & Yes & Yes & Yes \\
\hline$\rho$ & 0.81 & 0.81 & 0.81 \\
\hline
\end{tabular}

Notes: ${ }^{*} 10 \%$, ${ }^{\star *} 5 \%$, and ${ }^{* * *} 1 \%$ levels of statistical significance. Standard errors clustered at the county level.

Table 5. Sensitivity analysis of increased credit availability to loans from the Farm Credit System (FCS)

\begin{tabular}{|c|c|c|}
\hline & Log land value & Log land value \\
\hline & (1) & $(2)$ \\
\hline \multirow[t]{2}{*}{ Increased credit availability } & $0.2314^{\star \star \star}$ & \\
\hline & $(0.0265)$ & \\
\hline \multirow[t]{2}{*}{ Increased credit availability index } & & $0.2108^{\star \star \star}$ \\
\hline & & $(0.0267)$ \\
\hline \multirow[t]{2}{*}{ Farm credit system loans } & $0.0012^{\star}$ & $0.0011^{\star}$ \\
\hline & $(0.0007)$ & $(0.0042)$ \\
\hline \multirow[t]{2}{*}{ Constant } & $6.5641^{\star \star \star}$ & $6.5908^{\star \star \star}$ \\
\hline & $(0.3900)$ & $(0.3907)$ \\
\hline Determinants of land values & Yes & Yes \\
\hline Macroeconomic factors & Yes & Yes \\
\hline Observations & 866 & 866 \\
\hline Counties & 399 & 399 \\
\hline$R^{2}$ & 0.62 & 0.62 \\
\hline County fixed effects & Yes & Yes \\
\hline Year fixed effects & Yes & Yes \\
\hline$\rho$ & 0.91 & 0.91 \\
\hline
\end{tabular}

Notes: ${ }^{*} 10 \%$, ${ }^{\star \star} 5 \%$, and ${ }^{\star \star \star} 1 \%$ levels of statistical significance. Standard errors clustered at the county level. The decrease in observations is due to the fact that FCS call reports are not available for 2002. 
Table 6. Effects of one aggregated credit measure on land values using 2SLS

\begin{tabular}{|c|c|}
\hline & Log land value \\
\hline & $(1)$ \\
\hline \multirow[t]{2}{*}{ Return } & $0.0013^{* \star \star}$ \\
\hline & $(0.0003)$ \\
\hline \multirow[t]{2}{*}{ Increased credit availability index } & 0.2473 \\
\hline & $(0.1906)$ \\
\hline \multirow[t]{2}{*}{ Government payments } & 0.0035 \\
\hline & $(0.0054)$ \\
\hline \multirow[t]{2}{*}{ Population } & $0.0035^{\star \star \star}$ \\
\hline & $(0.0012)$ \\
\hline \multirow[t]{2}{*}{ Fixed interest rate } & $-0.0618^{\star * \star}$ \\
\hline & $(0.0093)$ \\
\hline \multirow[t]{2}{*}{ Number of operations with internet } & $0.0013^{\star \star \star}$ \\
\hline & $(0.0003)$ \\
\hline \multirow[t]{2}{*}{ Population growth } & $0.0185^{\star \star}$ \\
\hline & $(0.0081)$ \\
\hline \multirow[t]{2}{*}{ House value } & 0.0064 \\
\hline & $(0.0051)$ \\
\hline \multirow[t]{2}{*}{ Metro County } & 0.1048 \\
\hline & $(0.1003)$ \\
\hline \multirow[t]{2}{*}{ Debt-to-income ratio } & 0.0279 \\
\hline & $(0.0251)$ \\
\hline \multirow[t]{2}{*}{ Unemployment rate } & -0.0100 \\
\hline & $(0.0122)$ \\
\hline \multirow[t]{2}{*}{ Farm income per capita } & $0.0229^{\star \star \star}$ \\
\hline & $(0.0046)$ \\
\hline \multirow[t]{2}{*}{ Incomplete high school } & $-0.0285^{\star \star \star}$ \\
\hline & $(0.0052)$ \\
\hline Observations & 1,488 \\
\hline$R^{2}$ & 0.51 \\
\hline Counties & 505 \\
\hline Kleibergen-Paap rk LM Statistic & 25.458 \\
\hline Kleibergen-Paap rk F Statistic & 27.80 \\
\hline RMSE & 0.37 \\
\hline \multicolumn{2}{|l|}{ First stage instrument } \\
\hline \multirow[t]{2}{*}{ Expected demand for loans } & $-0.0027^{\star \star \star}$ \\
\hline & $(0.0005)$ \\
\hline F-Statistic for IV in first stage & 27.80 \\
\hline Endogeneity test statistic & 0.001 \\
\hline
\end{tabular}

Notes: ${ }^{\star} 10 \%,{ }^{\star \star} 5 \%$, and ${ }^{\star \star \star} 1 \%$ levels of statistical significance. Standard errors clustered at the county level. Increased credit availability is instrumented by the expected demand of loans. The endogeneity test is the Hausman test. 
increased or remained unchanged in the past months ${ }^{9}$; and (c) more bankers assert the amount of collateral required to have decreased or remained unchanged in the past months, than the number of bankers stating that these conditions have deteriorated. We use a diffusion index of these variables to determine whether the majority of lenders responded higher or lower. Values above 100 of the diffusion index refer to a greater number of lenders reporting increases, while values below 100 indicate that the majority of lenders reported decreases. Bankers are asked about changes in (a) to (c) in comparison with the same time in the previous year. The formula for increased credit availability "Inc. Credit Avail." for county $i$ at year $t$ can be written as:

$$
\begin{array}{r}
\text { Inc. Credit Avail. } ._{\text {it }}=\{1 \text { if avf } \geq 100 \text { and } r r \geq 100 \text { and } c \geq 100, \\
0 \text { otherwise }\}
\end{array}
$$

where $a v f$ is available funds, $r r$ is repayment rates, and $c$ is collateral requirements. 100 refers to a value of the diffusion index as explained previously. We then expand the increased credit availability index to include variables from the FDIC (i.e. deposits and bank branches). The formula for the expanded version, the increased credit availability index for county $i$ at year $t$ can be written as:

$$
\begin{aligned}
& \text { Inc. Credit. Avail. Index } i t= \\
& \{1 \text { if Inc. Credit Avail. }=1 \text { and dep. }>\overline{\operatorname{dep}} \text { and } \operatorname{comp}>\overline{c o m p}, \\
& 0 \text { otherwise }\}
\end{aligned}
$$

where dep is the amount in bank deposits, $\overline{d e p}$ is the average of bank deposits in the state, comp is the number of different bank companies in a county, and $\overline{c o m p}$ is the average number of different banks in a state. The base case of 0 includes the status quo and decreased credit availability. In order to interpret the coefficients of Increased Credit Availability and Increased Credit Availability Index, we follow Kennedy $(1981)^{10}$.

The majority of agricultural loans are provided by commercial banks and through the Farm Credit System (FCS). Data from FDIC and Ag Credit Surveys only consider commercial banks. In order to test for the effect of loans made through the FCS on the index for increased credit availability, we estimate a regression with agricultural loans awarded through the FCS. The objective is to check whether the coefficient associated with increased credit availability was sensitive to the inclusion of this other source of credit. Lags of the amount of real estate agricultural loans made through the FCS are used to control for endogeneity issues.

As a robustness check for any remaining endogeneity issues between increased credit availability and land values, we run a two-stage least squares estimation (2SLS) (Wooldridge, 2013) using the expected demand for loans as an instrumental variable. Expectations of future demand for loans impact credit that is available today. Expectations that there will be an increase in the demand for loans in the upcoming months may motivate agricultural lenders to reduce the number of loans they make today in order to offer more loans in the future. Since demand for loans is forward-looking, we do not expect it to impact past land values and, thus, to be uncorrelated with the error term.

\footnotetext{
${ }^{9}$ Increased repayment rates indicate to lenders the borrowers' ability to service debt (Cowley, 2018). It means that the rate at which debt is being serviced is increasing. The number of borrowers repaying their loan is increasing. Similarly, lower repayment rates would mean lower ability to service debt, hindering lenders' ability to lend (Cowley, 2018).

${ }^{10}$ Kennedy (1981) argues that the correct measure $\left(\beta^{*}\right)$ of the parameter of a dummy is $\beta^{*}=e^{(\hat{\beta}-0.5 * \operatorname{Variance}(\hat{\beta})}-1$. Where $\beta$ is the parameter associated with increased credit availability or the increased credit availability index.
} 


\section{Results and Discussion}

Panel data models are used to estimate the effect of credit availability on land values. Tables $3,4,5$ and 6 provide the results from various specifications of the model. Table 3 displays results of the fixed effects regression for each of the factors related to credit availability separately (Columns 1-6) and jointly for all variables (Column 7). These results allow us to analyze the effects of credit availability on land values separately and how sensitive these effects are to changes in model specification. The findings are stable to changes in the model. Table 4 presents the results for the increased credit availability variable and the increased credit availability index. Table 5 presents a sensitivity analysis of how controlling for another major lending institution, the Farm Credit System may affect land values. Table 6 shows results from the 2SLS estimation.

Results presented in Table 3 show that the determinants of land values have similar effects as those found in previous literature. Returns to land per acre have a positive effect on land values, similar to findings by Featherstone and Baker (1987), while the effect of interest rates on land values are negative. Interest rates proxy potential earnings from other investments, and therefore, these move in opposite direction from asset prices (e.g. land values). We do not find that the use of internet has a statistically significant impact on land values. It may be that any effects that internet access may have on productivity or lending are already being captured by other variables (i.e. returns and the credit availability variables). We find that aggregate government payments have a negative effect on land values. The effects of these aggregate government payments on land values differ due to differences in the programs, payment times, and market/production conditions and regions (Ifft, Kuethe and Morehart, 2015; Goodwin, Mishra and Ortalo-Magne, 2003). This study is not the first to find a negative effect from government payments on land values. Goodwin, Mishra and OrtaloMagne (2003) find a negative impact on land values from certain government programs such as the disaster payments. Mishra, Moss and Erickson (2008) find a negative impact on land values from the percentage of income derived from government payments in six regions of the U.S.

Land values are driven by factors beyond the sum of expected returns. Urbanization pressures represented in our estimations by population, population growth, and housing values have a positive effect on land values, confirming findings from previous studies (Goodwin, Mishra and OrtaloMagne, 2003; Kropp and Peckham, 2015) (Table 3). While controlling for other county-specific factors, we find that unemployment rates have a negative effect on land values, while farm income has a positive effect. The unemployment rate and education levels can impact the non-agricultural economy. Improvements in the non-agricultural economy may put an upward pressure on land values. Similar to Dinterman and Katchova (2019) who find that increases in unemployment rates decrease cash rents, we find that increases in unemployment rates have a negative impact on land values. Farm income has a positive relationship with land values as found in past studies (Featherstone, Taylor and Gibson, 2017; Bashra, Zhang and Hart, 2020). We did not find the level of education nor the fact that the land is in a metro county to have a statistically significant effect on land values.

Table 3 presents a number of specifications to account for the individual effects from factors related to credit availability (i.e. variables from the Ag Credit survey and from FDIC). These individual effects on land values by factors that may influence credit availability (i.e. available funding, bank deposits, collateral requirements, and repayment rates) vary from $0.04 \%$ to $0.1 \%$, which are lower than the $1.4 \%$ effect of increases in loans on land values, estimated by Devadoss and Manchu (2007). These results suggest that increases in credit availability positively impact land values, though minimally in magnitude. When banks have more liquidity (i.e. higher availability of funds), they can grant more loans to farmers, therefore increasing the supply of credit. An increase of a million dollars in bank deposits increases land values by $0.04 \%$, while a $1 \%$ increase in the number of lenders who believe that fund availability increased with respect to the previous 3 months is associated with a $0.1 \%$ increase in land values. These impacts are close to the effects found by Rajan and Ramcharan (2015) for land values during the 1920s which, ranged between $0.06 \%$ and $0.07 \%$. Similarly, a $1 \%$ increase in lender's responses that the required collateral has 
increased with respect to the previous 3 months is associated with a $0.07 \%$ decrease in land values. Increases in the required collateral, though, were not found to have a significant effect on land values. This result may be attributed to the changes in banking regulations that switched the focus from collateral only to also include cash flows considerations. Similarly, we find no significant relationship between repayment rates and land values (Table 3). A possible explanation could be that since these loans were extended with collateral, lenders would not restrict credit based on repayment rates. Given that real estate loans have longer terms, it may be that lenders may expect that there would be periods of lower repayment rates. Results from Table 3 suggest that since bank regulations were adopted, the impacts of credit availability on land values may have declined. One caveat of these results is that they consider these credit availability factors individually.

The next models account for favorable credit conditions using an aggregated credit availability measure when borrowers face a lending environment where more bankers report lower collateral requirements, higher repayment rates, and increased available funds for loans than in the previous year. Results presented in Table 4 show that favorable conditions measured by an aggregated increased credit availability have larger effects on land values than when changes occur in one of the variables associated with credit availability (Tables 3 and 4). Table 4 shows that when the three credit availability variables are combined into an increased credit availability, the effect of credit availability on land values increases. A 0.1 increase in the variable measuring increased credit availability is associated with a $1.96 \%$ increase in land values ${ }^{11}$. A 0.1 increase in the increased credit availability index is associated with a $1.64 \%$ increase in land values ${ }^{12}$. These results highlight how studies that only consider the amount loaned as a proxy for credit availability may be underestimating its full effect on land values. The combination of increased bankers' reporting along with bank deposits and branch information can boost the effect of credit availability on land values significantly. Our results show that credit availability plays an important role in supporting land values, together with other determinants of land values, even though new lending regulations have been recently adopted.

As a next step, we check for the sensitivity of the increased credit availability index to the amount of loans awarded through the Farm Credit System (FCS) (Table 5). Given the limitations of the data available from the FCS call reports (see Section 3), our intent is to check whether accounting for FCS loans will decrease the effect from the scenario of increased credit availability. When including the FCS loans variable, we find that the effect of credit availability on land values increased to $2.34 \%$ in comparison to effect without the FCS loans variable, of $1.64 \%{ }^{13}$ (see Tables 4 and 5).

Last, we instrument the increased credit availability index using the lenders' expected demand for loans. Table 6 shows the results from the instrumental variable estimation. The KleibergenPaap test is above 10 indicating a strong instrument (Boberg-Fazlić and Sharp, 2015). The expected demand for loans has the expected statistically significant relationship to increased credit availability. However, the endogeneity test results suggest that the regressors should be treated as exogenous. Therefore, the results from Table 4 are valid, and there is no need to instrument the increased credit availability index. Yet, the effect of government payments on land values becomes insignificant in the 2SLS estimation.

\section{Conclusion}

Using panel data from Ag Credit Surveys and from the FDIC Summary of Deposits, we analyze the relationship between land values and credit availability. Fixed effects estimations were performed at the county level, controlling for land value determinants, credit availability factors,

\footnotetext{
${ }^{11}$ The impact of parameters is corrected using the formula from Kennedy (1981).

${ }^{12}$ The impact of parameters is corrected using the formula from Kennedy (1981).

${ }^{13}$ The impact of parameters is corrected using the formula from Kennedy (1981).
} 
and county and macroeconomic factors from several secondary data sources. We find that if the factors influencing credit availability individually increase by $1 \%$, they have a positive effect on land values that is below $0.5 \%$. To measure the effects of a favorable credit environment, we build an index of increased credit availability. Transitioning from an unchanged or decreased credit availability environment to an increased credit availability environment measured by a 0.1 increase in the credit availability index is associated with increased land values by $1.96 \%$ or $1.64 \%$ depending on the index that is used. Even after the regulatory changes in the lending system (e.g. greater consideration of cash flow and profitability and loan-to-value requirements), increased credit availability is still associated with upward pressure on land values. The combination of multiple factors moving toward a favorable credit environment can have greater effects on land values than changes in a single factor associated with credit availability. This result points to the need to consider credit availability as a combination of factors. Using only liabilities to proxy credit may underestimate the effect of credit availability, especially since it measures the accumulated total amount of loans at a bank rather than the actual amount loaned in a given year or quarter.

Land serves as an indicator of farm financial health (Cowley, 2018). Therefore, agricultural lenders need to be aware of the impacts of credit availability on land values to be able to accurately predict future changes in land values. This foresight allows lenders to assess and mitigate the risks associated with loans they grant and better manage their loan portfolios. Government programs aimed at increasing credit availability to facilitate land acquisitions may, in fact, inflate land values and make land acquisition more challenging. Increases in farmland prices may reduce the number of farm businesses that are financially vulnerable (Burns et al., 2018). However, by facilitating credit access with the purpose of increasing land ownership, government programs may be, in fact, putting pressure on farms with high debt-to-asset ratios to exit farming. In contrast, land value appreciation favors those who already own the majority of land they operate (Burns et al., 2018), while creating barriers of entry into farming. Farmers with land may experience greater access to credit, potentially increasing their demand for land (Burns et al., 2018), which could further lead to the concentration of land ownership. This may result in greater inequality with respect to land acquisition and further challenges to beginning farmers. If the goal is to increase land ownership, especially for beginning farmers, a potential remedy to limit the effect of credit availability on land values could be to increase credit supply to certain groups (e.g. beginning farmers). Further investigation is warranted to understand whether the proposed solutions can minimize the effects of credit availability on land values. This study has some limitations. As mentioned, we could not fully account for credit extended through other lenders when examining the effects of credit availability on land values. Nevertheless, we are confident that the perceptions of lenders from the Ag Credit Survey will likely mirror those in other lending agencies.

Acknowledgments. The authors would like to thank the Editor and four anonymous reviewers. The authors also appreciate comments received by Jeffrey Dorfman, Gerald Shively, and participants at the AAEA 2019 Early Career Professional 2-Day Post-Conference Workshop. Scientific Article No. 3381 of the West Virginia Agricultural and Forestry Experiment Station, Morgantown. The authors also thank Nathan Kauffman and others at the Federal Reserve Bank of Kansas City for helpful comments following the presentation of this research. The views expressed herein are those of the authors and do not reflect the Federal Reserve Bank of Kansas City, the Federal Reserve Bank of Minneapolis, or the Federal Reserve System.

Conflict of Interest. None.

\section{References}

Barry, P.J., Ellinger, P.N., Hopkin, J.A. and Baker, C.B. Financial Management in Agriculture, 7th ed. Upper Saddle River, NJ: Prentice Hall, 2012.

Bashra, A., Zhang, W., \& Hart, C. “The Impacts of Interest Rate Changes on US Midwest Farmland Values.” Working Paper. Department of Economics, Iowa State University, 2020. Internet site: https:/www2.econ.iastate.edu/faculty/zhang/ publications/working-papers/Basha_Zhang_Hart_2020_Interest_Rate_Land_Value.pdf (Accessed August 6, 2020). 
Bellemare, M.F., T. Masaki, and T.B. Pepinsky. "Lagged Explanatory Variables and the Estimation of Causal Effect." The Journal of Politics 79(July 2017):949-63.

Bellemare, M.F., and N. Nguyen. "Farmers Markets and Food-Borne Illness." American Journal of Agricultural Economics 100(April 2018):676-90.

Bigelow, D., A. Borchers, and T. Hubbs. 2016. U.S. Farmland Ownership, Tenure, and Transfer. Washington, DC: U.S. Department of Agriculture, Economics Research Service, Economic Information Bulletin No. EIB-161, 2016.

Boberg-Fazlić, N.and P. Sharp. "Does Welfare Spending Crowd Out Charitable Activity? Evidence from Historical England Under the Poor Laws.” The Economic Journal 127(February 2015):50-83.

Borchers, A., J. Ifft, and T. Kuethe. "Linking the Price of Agricultural Land to Use Values and Amenities." American Journal of Agricultural Economics 96(June 2014):1307-20.

Briggeman, B.C., S.R. Koenig, and C.B. Moss. 2012. "US Farm Debt: The Role of ARMS.” Agricultural Finance Review, 72(July 2012):254-61.

Briggeman, B.C., C.A. Towe, and M.J. Morehart. "Credit Constraints: Their Existence, Determinants, and Implications for U.S. Farm and Nonfarm Sole Proprietorships.” American Journal of Agricultural Economics 91(February 2009):275-89.

Burns, C., N. Key, S. Tulman, A. Borchers, and J. Weber. Farmland Values, Land Ownership, and Returns to Farmland, 2000-2016. Washington, DC: U.S. Department of Agriculture, Economics Research Service, Economic Research Report No. ERR-245, 2018.

Ciaian, P., J. Fałkowski, and d. Kancs. "Access to Credit, Factor Allocation and Farm Productivity: Evidence from the CEE Transition Economies." Agricultural Finance Review 72(May 2012):22-47.

Cole, R.A. "The Importance of Relationships to the Availability of Credit." Journal of Banking \& Finance 22(August 1998):959-77.

Cowley, C. “Mapping Stress in Agricultural Lending.” Federal Reserve Bank of Kansas City Economic Review, 103(September 2018):5-29.

Devadoss, S., and V. Manchu. "A Comprehensive Analysis of Farmland Value Determination: A County-Level Analysis." Applied Economics 39(April 2007):2323-30.

Dinterman, R. and A.L. Katchova. "Property Tax Incidence on Cropland Cash Rent." Applied Economic Perspectives and Policy 42(April 2019):1-20.

Drescher, K., and K.T. McNamara. "Determinants of German Farmland Prices." 39th Congress of the European Regional Science Association: "Regional Cohesion and Competitiveness in 21st Century Europe", August 23-27, 1999. Internet site: http://hdl.handle.net/10419/114210 (Accessed December 10, 2020).

ERS/USDA, Farm Income and Wealth Statistics. "Farm Sector Balance Sheet, 1960-2020F”. Internet site: https://data.ers. usda.gov/reports.aspx?ID=17835 (Accessed December 11, 2020)

Featherstone, A.M., and T.G. Baker. "An Examination of Farm Sector Real Asset Dynamics: 1910-85." American Journal of Agricultural Economics 69(August 1987):532-46.

Featherstone, A.M., M.R. Taylor, and H. Gibson. "Forecasting Kansas Land Values Using Net Farm Income." Agricultural Finance Review, 77(May 2017):137-52.

Fletschner, D. "Women's Access to Credit: Does It Matter for Household Efficiency?" American Journal of Agricultural Economics 90(August 2008):669-83.

Goodwin, B.K., A.K. Mishra, and F. Ortalo-Magné. "What's Wrong with Our Models of Agricultural Land Values?" American Journal of Agricultural Economics 85(August 2003):744-52.

Goodwin, B.K., A.K. Mishra, and F. Ortalo-Magné. The Buck Stops Where? The Distribution of Agricultural Subsidies. Cambridge, MA: National Bureau of Economic Research, Working Paper No. 16693, 2011. Internet site: http://www. nber.org/papers/w16693 (Accessed December 14, 2017).

Guttentag, J. “Credit Availability, Interest Rates, and Monetary Policy.” Southern Economic Journal 26(January 1960):219-28.

Hartarska, V., D. Nadolnyak, and X. Shen. "Agricultural Credit and Economic Growth in Rural Areas.” Agricultural Finance Review 75(September 2015):302-12.

Hartarska, V., and D. Nadolnyak. "Financing Constraints and Access to Credit in a Postcrisis Environment: Evidence from New Farmers in Alabama." Journal of Agricultural and Applied Economics 44(January 2012):607-21.

Hennessy, T., D. Läpple, and B. Moran. “The Digital Divide in Farming: A Problem of Access or Engagement?” Applied Economic Perspectives and Policy 38(July 2016):474-91.

Ifft, J., T. Kuethe, and M. Morehart. "The Impact of Decoupled Payments on US Cropland Values." Agricultural Economics 46(April 2015):643-52.

Just, R.E., and J.A. Miranowski. "Understanding Farmland Price Changes." American Journal of Agricultural Economics 75(February 1993):156-68.

Keeton, W.R. "Do Bank Mergers Reduce Lending to Businesses and Farmers? New Evidence from Tenth District States." Federal Reserve Bank of Kansas City Economic Review 81(1996):63-76.

Kennedy, P.E. "Estimation with Correctly Interpreted Dummy Variables in Semilogarithmic Equations." American Economic Review, 71(September 1981):801. 
Koenig, S. Ag Loan Volume Grows at Farm Banks: Loan Quality is Declining. McLean, VA: Farm Credit Administration, Office of Regulatory Policy, Economic Report, September 2016.

Kropp, J. and J.G. Peckham. "U.S. Agricultural Support Programs and Ethanol Policies Effects on Farmland Values and Rental Rates." Agricultural Finance Review 75(July 2015):169-93.

Kuethe, T., J. Ifft, and M.J. Morehart. “The Influence of Urban Areas on Farmland Values.” Choices 26(April 2011):1-7.

Mishra, A.K., C.B. Moss, and K.W. Erickson. "The Role of Credit Constraints and Government Subsidies in Farmland Valuations in the U.S.: An Options Pricing Model Approach.” Empirical Economics 34(February 2008):285-97.

Moss, C.B., and A.L. Katchova. "Farmland Valuation and Asset Performance." Agricultural Finance Review 65(July 2005):119-30.

Nadolnyak, D., X. Shen, and V. Hartarska. "Farm income and output and lending by the farm credit system", Agricultural Finance Review 77(May 2017):125-136.

Pederson, G., W. Chung, and R. Nel. "Microeconomic Impacts of a State-Funded Farmer Loan Program." Agricultural Finance Review 72(October 2012):5-21.

Rajan, R., and R. Ramcharan. "The Anatomy of a Credit Crisis: The Boom and Bust in Farm Land Prices in the United States in the 1920s." American Economic Review 105(May 2015):1439-77.

Shalit, H., and A. Schmitz. "Farmland Accumulation and Prices." American Journal of Agricultural Economics 64(November 1982):710-9.

Shalit, H., and A. Schmitz. "Farmland Price Behavior and Credit Allocation." Western Journal of Agricultural Economics 9(1984):303-13.

Wooldridge, J.M. Introductory Econometrics: A Modern Approach, 5th ed. Mason, OH: South-Western Cengage Learning, 2013.

Zakrzewicz, C.J., B.W. Brorsen, and B.C. Briggeman. "Accuracy of Qualitative Forecasts of Farmland Values from the Federal Reserve's Land Value Survey.” Journal of Agricultural and Applied Economics, 45(February 2013):159-70.

Zhang, W., and K. Tidgren. "The Current Farm Downturn vs the 1920s and 1980s Farm Crises: An Economic and Regulatory Comparison.” Agricultural Finance Review 78(August 2018):396-411.

Cite this article: Sant'Anna AC, Cowley C, and Katchova AL (2021). Examining the Relationship between Land Values and Credit Availability. Journal of Agricultural and Applied Economics 53, 209-228. https://doi.org/10.1017/aae.2020.32 